\title{
Outsourcing Public Employment Services: The Australian Experience
}

\author{
Elizabeth Webster and Glenys Harding \\ Melbourne Institute of Applied Economic and Social Research \\ The University of Melbourne
}

Melbourne Institute Working Paper No. 4/00

\begin{abstract}
March 2000
This paper was undertaken for the New Zealand Treasury. It represents the authors' own views and not those of the New Zealand Treasury. We would like to thank John Creedy,

Don Harding and two referees for the NZ Government for comments and useful suggestions.

ISSN 1328-4991

ISBN 0734014848

Melbourne Institute of Applied Economic and Social Research The University of Melbourne

Victoria 3010 Australia

Telephone (03) 93445288

Fax (03) 93445630

Email melb.inst@iaesr.unimelb.edu.au

WWW Address http://www.ecom.unimelb.edu.au/iaesrwww/home.html
\end{abstract}




\begin{abstract}
While privatising or tendering out government infrastructure and public works services has become commonplace in Australia, its incursion into human services is comparatively new. Some outsourcing issues and problems are common to both types of service but the welfare or human dimension also brings forth different complexities. This paper discusses the theoretical rationale for outsourcing existing government services in the context of empirical studies. It also provides a short history of outsourcing in Australian job placement and labour market programs. Although large scale outsourcing placement services occurred two years ago (May 1998) with the introduction of the Job Network, there has been no published formal evaluations undertaken due to the lack of publication of administrative data.
\end{abstract}


CON TEN TS

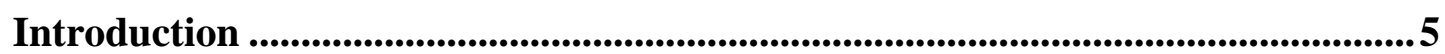

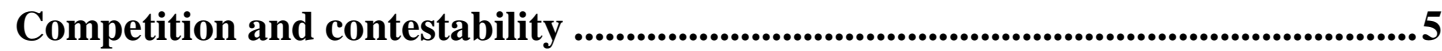

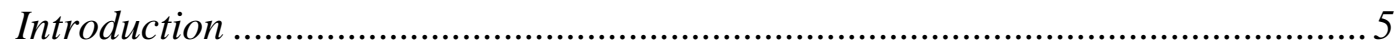

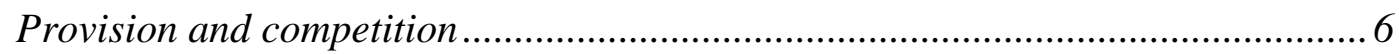

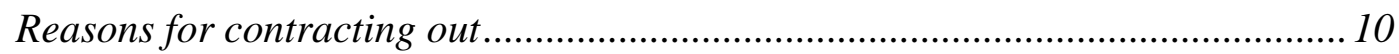

Effects of general contracting out (Australia) ..................................................... 11

Employment programs in Australia ..............................................................15

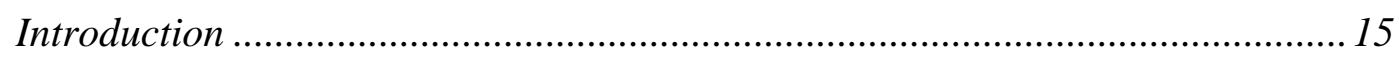

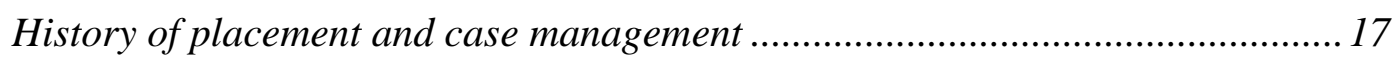

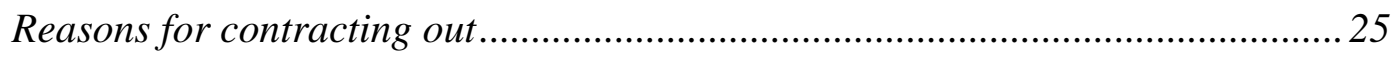

Mechanisms used to support contestability ......................................................2 27

Effects of contracting employment services (Australia) ...................................... 30

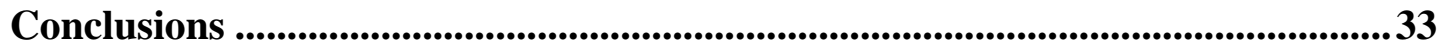

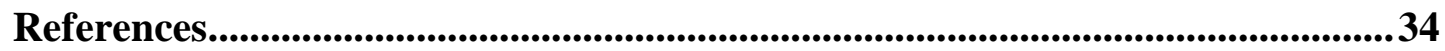




\section{IN T RO D U C T IO N}

Since the mid-1990s, there has been a steady growth in the propensity for government organisations to outsource their human welfare related services. By 1998 a wholesale tendering of employment services under the Job Network program was undertaken. In order to place this reform in context, this paper discusses the theoretical rationale for outsourcing existing government human services and provides a short contextual history of outsourcing in Australian placement and labour market programs. Although major outsourcing placement services occurred in May 1998 with the introduction of the Job Network, there has been no published formal evaluations undertaken due to the lack of publication of administrative data.

The first section of this paper discusses the role competition and contestability should play in the provision government services. The second section presents a brief market structure history of Australian job placement and case management services. A short conclusion follows.

\section{COM PETIT ION AN D CON TESTABIITY}

\section{Introduction}

The intensity of competition and the ownership structure of a market are related but not necessarily linked economic phenomena. However, most government-funded activities are provided by the government and most government provided services have been protected from competitive market forces. There are examples of government funded but privately operated services that are open to external competition (waste collection). 
Furthermore, there are many examples of government funded and government provided services that are fully open to competition from private or community sources (airlines, telecommunications, education). However, there is also a large body of welfare-related services, which are government funded and government provided but are shielded from competition and market incentives. In Australia, these are mainly services that have been provided to guarantee minimum consumption levels across the population in accordance with community notions of economic justice and equality. Examples include free provision of primary and secondary education, free health care, subsidised public housing and food.

The remaining parts of this section outlines the economic reasons for government involvement in both the funding and provision of certain goods and services. In particular it analyses why the combination of public funding, public provision and the restriction of competition is found in some markets. An overview of some recent Australian evidence of the effects of contracting out a range of government funded services follows.

\section{P rovision and com petition}

Competition between many sellers for customers and competition by these customers for the services of these suppliers is essential to economists' understanding of how atomistic market economies organise and distribute production. Without centralised direction, some mechanism must exit to prevent economic chaos. Competition directs labour and resources to areas of greatest pecuniary need and ensures that producers do not charge more than cost plus 'normal' profit and that consumers do not drive prices so low that producers cannot recover this profit. Competitive pressure exercises constraints on 
activities and drives producers to keep prices down ${ }^{1}$, to organise according to the best known techniques of production and to innovate in order to avoid economic annihilation.

It was once held that a large number of buyers and sellers were required to fuel this process. However, it has more recently been suggested that an active threat of entry may be enough to force incumbents to conform to desirable competitive behaviour (Baumol 1982). Markets with a plausible threat of entry are described as contestable markets. The lower are market entry and exist costs, the more contestable or competitive a market will be and consequently the greater its static and dynamic efficiency. Entry/exit costs include high minimum levels of capital (investment) required before production can begin, restricted access to best practice technologies and information, and legal prohibitions.

While governments have dominated the provision of many welfare or community services, it is rare for private providers to be excluded from these markets. However, because governments provide most of the funding for many services, lack of access to these funds can make a market uncontestable or uncompetitive. Government funding is justified on the grounds that purely private provision will result in sub-optimal consumption levels where positive social externalities are present and economic justice principles are relevant. A broad distribution of education and health services, broader than would arise under pure private arrangements, may be required to satisfy economic justice principles for example. An above-market level of job matching may be required to internalise positive social externalities, which occur when benefits are reaped by the general community (in the form of lower taxes or more services) as well as the jobseeker and the employer. Governments have sought to affect consumption rates by free provision of services, sometimes in collaboration with regulations demanding minimum

\footnotetext{
${ }^{1}$ For a good or service of a given quality.
} 
levels of consumption (such as minimum level of education, vaccinations, and job search).

However, while a clear case exists for the government to fund a portion of some welfare services, it does not immediately follow that they must also provide all or any of, these services. Furthermore, even if the government defines itself as a major provider, it is not necessary that the government should limit competition between the different arms of its provider network.

In practice, government provision has been common in welfare markets because it apparently avoids (or minimises) the need to monitor the quality service provision by providers and the satisfactory consumption of services by individuals who would otherwise consume a sub-optimal level. In general, there is no monitoring problem in the private situation where the consumer pays the producer directly for the good or service they consume. If the consumer is well informed about the quality of the commodity ${ }^{2}$ a contestable market allows them to seek these goods and services from other producers if they are dissatisfied. Loss of revenue thus acts as a discipline upon producers to cater for consumer needs in a cost-effective manner. However, when the government pays but does not consume these services, it is more difficult to monitor whether or not the provider is producing in an effective manner. The government at the end of the day is, and must be, accountable for outcomes. If it cannot devise a cost effective accountability mechanism for private providers, then it is easier to retain direct control over provision.

To manage an outside agency, a three-cornered incentive and monitoring system must be instigated to replicate the desirable attributes of a market exchange (internal drive to be cost effective, imperative to innovate, appropriate response to changing 
market requirements) without the undesirable equity and under-consumption features. Such a system can be expensive and subject to inaccuracies and errors, especially in markets where the service is difficult to define, the commodity is heterogeneous and the clients disinterested. It is probable that the event of cheap on-line electronic information technologies has made complex incentive and monitoring systems cost effective and workable. Governments may choose to retain responsibility for provision in areas where they do not believe they are able to closely assess what the provider is doing and whether they are acting in the public interest. The difficulty of designing enforceable contracts when many unknown contingent futures are likely can also lead to a preference for government provision.

However, it is erroneous to conclude that the difficulties of defining and measuring a welfare outcome implies that government provision is preferred. Most contemporary public bureaucracies are struggling with the issue of how to monitor and motivate their own internal operations as well. To manage effectively they need some way to define and measure internal performance. Neither does it follow that all welfare services are difficult to define and dependent on uncertain contingencies. 'Meals-on-wheels', books borrowed and a successful job match are easy to define and measure. Furthermore, it is misleading to imply that outsourced providers of these services are less intrinsically interested in the welfare of their clients or are unprofessional in their service delivery. Many organisations who have successfully tendered as employment placement or welfare service providers in Australia are well known charities and churches. Many of these organisations would regard the provision of the services under discussion as complementary to their existing activities.

\footnotetext{
${ }^{2}$ An exception could be health, education and some technical services.
} 
A market of government funded and government provided services does not necessarily preclude competition between different supplying agencies. In most cases competition can be introduced by designing bureaucratic incentive structures which mimic market signals. Government schools in many countries today are funded on their ability to attract students (who have freedom to chose between schools) and school principals have been given progressively more and more autonomy over expenditure and staffing. However, competition often comes at the expense of co-operation and this model may not have been thought suitable to other welfare services, especially those where the scope for innovation and cost cutting is small or viewed as less important.

\section{Reasons forcontracting out}

Outsourcing or contracting out of government funded services is generally used as a device to capture some of the desirable features of a free market, such as the incentives to produce at minimum cost, innovate and respond to changing market needs. If these qualities can be harnessed without sacrificing the equity and quality of service attributes required of the industry, then there should be, in theory, a social gain.

According to the Australian Industries Commission (IC, 1996) much of the value from competitive tendering arises from requiring agencies to review what they are doing and forcing a cultural change upon the workplace. These changes can of course also be directed by bureaucratic fiat, but it is a question of the quickest and most cost effective way for a peak body to affect these changes from above. Attitudes, behaviours and expectations can often be slow to change by mere exhortation and education. Contracting out has thus been employed as a device for quick wholesale reform of public sector work practices. 
Nevertheless, the government cannot delegate accountability for outcomes. They must always retain control over the translation of broad objectives into detailed service specifications, they must ensure that the service is delivered and that the service is given equitably and responsibly. While the introduction of an intermediary can hinder accountability, the Industries Commission (IC, 1996) has argued that this may be counterbalanced by the greater clarity over the definition and evaluation of responsibilities and outcomes required by the tendering process. It is plausible to assume that the trend toward outsourcing many government services has been assisted by the availability of cheap and efficient information and monitoring systems available through on-line computer systems.

\section{E ffects ofgeneralcontracting out (A ustralia)}

Australian studies of contracting out cover a range of government services, from mail delivery to refuse collection. However, for practical reasons, measurement is generally confined to short-term price or cost outcomes. Most of the examples, summarised in Table 1 below, found that tendering had resulted in lower unit costs. Efficiency gains arose from better management and work practices, access to better skills, and better use of capital. While there were several changes to the quality of the service provided, these did not systematically account for the lower unit costs. Some, but not all cost savings, were nevertheless gained through lower wages. In addition, the tender process often forced the accountable body (in these cases the government) to explicitly state and clarify the responsibilities of relevant parties. 
In its summary of both Australian and overseas studies, the Industry Commission (IC, 1996) identified some issues to be considered when deciding whether or not to tender. These include:

- Short contracts can reduce incentives for ongoing investment especially in research and development, and training; however, long contracts may carry greater risks of inadequate performance, and may also reduce the policy flexibility available to governments.

- In limited competitive markets, the contractor may become a monopoly and eventually charge monopoly prices. This is more likely to occur in thin or emerging markets.

- Loss of information flows, skills and the associated knowledge in government sector can reduce the government's longer-term ability to devise policy.

- High costs of tendering, monitoring, evaluation, especially where the service is difficult to quantify.

- Fixed costs of redundancies, retaining staff in government to oversee tender process (tender, monitor, evaluate).

- Whether an incentive system can be developed which does not give rise to creaming or a reduction in service quality.

- Lack of competitive interest in thin markets, especially isolated markets.

Services which have high privacy or national security implications may not be suitable for contracting out. This may include certain defence activities, Medicare and some services within the justice sector. Other concerns are associated with accountability - particularly identifying who is responsible if there is a service failure and the ability and 
avenues for consumer redress. However, many of the grounds for excluding private provision, can be surmounted if complementary regulations and monitoring devices are employed. The Industries Commission concluded that the decision to contract out should be looked at on a case by case basis. To overlook some services on the basis of privacy or welfare grounds, without investigating the option for ameliorating sensitive issues, may be to forgo efficiency gains. 
Table 1. Summary of evaluations of outsourcing physical services

\begin{tabular}{|c|c|c|c|c|c|}
\hline STUDY & COUNTRY & $\begin{array}{l}\text { DATE OF } \\
\text { EVALUAT } \\
\text { ION }\end{array}$ & $\begin{array}{l}\text { INDUSTRY/COMMODI } \\
\text { TY }\end{array}$ & $\begin{array}{l}\text { EVALUATION } \\
\text { METHOD }\end{array}$ & OUTCOME \\
\hline $\begin{array}{l}\text { Cubbin, Domberger \& } \\
\text { Meadowcroft, } 1987\end{array}$ & $\begin{array}{l}317 \text { Local Authorities in } \\
\text { England and Wales }\end{array}$ & $1984-85$ & Refuse collection services & $\begin{array}{l}\text { Efficiency gains using the } \\
\text { Farrell method of } \\
\text { identifying technical } \\
\text { efficiency. }\end{array}$ & $\begin{array}{l}\text { Bulk of efficiency gains from greater productivity of } \\
\text { labour and vehicles, not lower wages and fringe } \\
\text { benefits. }\end{array}$ \\
\hline $\begin{array}{l}\text { Domberger \& Rimmer, } \\
1994\end{array}$ & $\begin{array}{l}\text { Broad review of literature } \\
\text { in all countries }\end{array}$ & & & & $\begin{array}{l}\text { Leads to a substantial reduction in service costs - in } \\
\text { the order of } 20 \% \text {; process of competitive bidding is } \\
\text { key source of efficiency gains; no consensus on } \\
\text { service quality. }\end{array}$ \\
\hline $\begin{array}{l}\text { Domberger \& Piggott, } \\
1994\end{array}$ & Australia & & $\begin{array}{l}\text { Privatisation of public- } \\
\text { trading enterprises }\end{array}$ & & $\begin{array}{l}\text { Franchising is an appropriate mechanism for } \\
\text { privatisation when the market is inherently } \\
\text { monopolistic and/or when the government desires to } \\
\text { retain control over output and/or price. }\end{array}$ \\
\hline $\begin{array}{l}\text { Domberger, Meadowcroft } \\
\& \text { Thompson, } 1994\end{array}$ & England and Wales & $\begin{array}{l}1983 / 84 \\
\text { and } \\
1984 / 85\end{array}$ & Refuse collection services & $\begin{array}{l}\text { Regression analysis, using } \\
\text { cost function. }\end{array}$ & $\begin{array}{l}\text { Costs are lower (about } 22 \% \text { ) where tendered; } \\
\text { introduction of competition is factor in achieving } \\
\text { lower costs }\end{array}$ \\
\hline Domberger, 1994 & $\begin{array}{l}\text { Australia - NSW } \\
\text { government agencies }\end{array}$ & 1993 & Government agencies & Cost savings, employment. & $\begin{array}{l}\text { Expenditure savings of } 20 \% \text {; quality of services did } \\
\text { not appear to be traded off against savings; } \\
\text { ambiguous on employment. }\end{array}$ \\
\hline $\begin{array}{l}\text { Domberger, Hall \& Li, } \\
1995\end{array}$ & $\begin{array}{l}\text { Australia - Sydney } \\
\text { metropolitan region }\end{array}$ & $\begin{array}{l}\text { October } \\
1992 \text { to } \\
\text { June } 1993\end{array}$ & 61 cleaning contracts & $\begin{array}{l}\text { Two-equation econometric } \\
\text { model explaining the } \\
\text { determination of contract } \\
\text { priced and performance. }\end{array}$ & $\begin{array}{l}\text { Dominant influence of competition rather than } \\
\text { ownership on prices and quality; introduction of } \\
\text { competition results in quality being maintained or } \\
\text { sometimes enhanced. }\end{array}$ \\
\hline Domberger \& Li, 1995 & $\begin{array}{l}\text { Australia - Sydney } \\
\text { metropolitan region }\end{array}$ & $\begin{array}{l}\text { October } \\
1992 \text { to } \\
\text { June } 1993\end{array}$ & 61 cleaning contracts & $\begin{array}{l}\text { Ordered-Probit analysis of } \\
\text { price and performance. }\end{array}$ & $\begin{array}{l}\text { Contract price is exogenous in performance equation; } \\
\text { competitive tendering did not reduce observed } \\
\text { cleaning performance. }\end{array}$ \\
\hline $\begin{array}{l}\text { Domberger, Hall \& } \\
\text { Jeffries, } 1995\end{array}$ & Australia & 1994-95 & $\begin{array}{l}\text { Commonwealth } \\
\text { Government budget-funded } \\
\text { agencies }\end{array}$ & $\begin{array}{l}\text { Correlation analysis of } \\
\text { reasons for contracting and } \\
\text { assessment of outcomes } \\
\text { achieved. }\end{array}$ & $\begin{array}{l}\text { Savings achieved through contracting are substantial; } \\
\text { no apparent trade-off for lower quality of service. }\end{array}$ \\
\hline Hodge, 1996 & $\begin{array}{l}\text { Review of international } \\
\text { evidence }\end{array}$ & & & Meta-analytic review. & $\begin{array}{l}\text { Cost reduction of around } 9 \%-14 \% \text {; average quality } \\
\text { changes under contracting are not significantly } \\
\text { different to zero. }\end{array}$ \\
\hline
\end{tabular}




\section{EM PLOYMEN T PROGRAM S IN AUSTRALIA}

\section{Introduction}

The academic revival of interest in theories of competition and contestability has penetrated the Australian government community since the 1980s and routinely placed outsourcing and privatisation on the policy reform agenda. ${ }^{3}$ More specifically a heightened awareness of the distinction between the funding and the provision of public services has gone hand-in-hand with the growth in the outsourcing of government physical and infrastructure services in both Australia and overseas. However, the incursion of outsourcing into the realm of human services is more recent and experimental.

Australian had has a long history of public provision of employment services and program. Records, which date from the mid- $19^{\text {th }}$ century, included government funded public works programs during the economic downturns of the 1840s, 1890s, and 1930s. Government funded placement programs have existed since before $1940^{4}$ and in the three decades following the Second World War, several employment programs, predominantly aimed to reduce skill shortages, existed. Since the election of the Labor Government in 1972, there have been, at varying levels, large scale government funded job creation, training and wage subsidy programs. These expanded in 1987 to include more complex

\footnotetext{
${ }^{3}$ During the early 1980s, Professor Michael Porter from the Centre of Policy Studies (Monash University) ran frequent (and popular) seminars and conferences on the benefits to be gained from privatising government services and instrumentalities.

${ }^{4}$ Several Commonwealth and states agencies operated until the Second World War. These were replaced by the wartime Manpower Directorate that had certain powers over civilian worker and employers.
} 
placement services such as job search training, intensive job counselling and case management.

The first government funded case management program, JobLink (now the Community Business Employment Program), began as a Victorian Government initiative in 1987 and was subsequently copied by the Commonwealth Government and other state governments. Commonwealth job search training programs began in 1988.

Contracting the non-profit community and private sectors to provide job creation, wage subsidy and training programs has been an integral part of the Australian labour market program system since the 1970s, largely because of the need to access the resources and skills of the non-government sector. It was not possible to employ these skills because of economies of scale. Accordingly, it is much cheaper to buy training places in specialist courses at different times and locations than to run them directly from the employment service. However, outsourcing job placement, the right to refer or assign jobseekers to labour market programs and case management services is relatively new. The first outsourcing of case management occurred in Victoria in late 1988. Since May 1998, the bulk of Commonwealth placement and case management services (which provide the vast majority of funds in Australia) have been provided by the nongovernment sector.

This section outlines the history of placement and case management by the Victorian and Commonwealth Governments, discuss reasons for increasing the contestability of employment services, mechanisms used to support contestability and summarise results from several labour market program evaluations. 
$\mathrm{H}$ istory ofplacem entand case m anagem ent

O verview of the placem ent industry in A ustralia

Australian employment placement or job broking has traditionally been an industry

shared between the public and private sectors. The Commonwealth Employment Service (CES), which operated from 1946 to 1998, has been the main government placement service in Australia but state governments have run, from time to time, smaller agencies. The central goal of the CES was to improve the operation of job markets by operating a clearing house for job vacancies (which employers can lodge voluntarily) and offering free placement services for any interested employer or jobseeker. In addition, the CES was required to notify the Department of Social Security (DSS) of any breaches to the work test by unemployment benefit recipients. For many years, merely visiting the CES each week was considered enough to pass the test, however this requirement has been strengthened over time. Since 1989, a system of mutual/reciprocal obligation was instituted which required all unemployment benefit recipients to accept any reasonable offer of a job, a labour market program or a training position. Accordingly, some of the responsibility for reporting a failure to comply with the work test, or mutual obligation was given to case managers. Not surprisingly, unemployed and less skilled job seekers tended to be over-represented among CES clientele compared with the general job seeker population. $^{5}$

A wide array of commercial placement services co-existed with the CES. These usually operated in niche occupational labour markets for the benefit of the prospective employers who paid fees. Private agencies have no obligation to find or act on behalf of any interested job seeker and accordingly, give selective assistance to jobseekers 
(Boreham, Roan and Whitehouse, 1994). Over half of private agency jobseekers are already in employment.

Most successful job placements for people who were not previously employed however, occur regardless of the activities of either type of placement service. From 1982 to1997, the Australian Bureau of Statistics survey of job attainment indicated that the CES was instrumental in the successful job match of about 10 per cent of cases, while private employment agencies were involved in less than 2 per cent. The 1998 survey reported a dramatic drop in the proportion of successful job seekers who attributed their success to the CES/Centrelink, however this is likely to be due to temporary confusion created by the introduction of the new regime. In all survey years, most jobs were obtained after the jobseeker directly approached the employer, sought information through friends and contacts or replied to newspaper advertisements (see Table 2).

T able 2. P ercentage distribution ofpreviously out of w ork persons w ho started a job during the previous $12 \mathrm{~m}$ onths.M ethod of job attainm ent form ost recently obtained job, Australia, July 1982 to July 1998.

\begin{tabular}{lllll}
\hline Method & July 1982 & June 1986 & July 1996 & July 1998 \\
\hline Cold calling employers & 24.8 & 21.8 & 18.4 & 19.7 \\
Newspaper advertisements & 17.1 & 17.6 & 25.7 & 15.4 \\
Friends, contacts* & 18.0 & 17.9 & 19.6 & 20.8 \\
CES/Centrelink** & 10.0 & 12.1 & 9.9 & 6.4 \\
Private employment agency & 1.5 & 1.2 & 1.3 & 1.5 \\
Other & 34.5 & 29.4 & 25.1 & 36.2 \\
TOTAL & 100 & 100 & 100 & 100 \\
\hline
\end{tabular}

Source: ABS cat. 6245.0. Standard Data Service 6222.0.40.001.

Notes: * Does not include people who initiated the approach to family and friends. These are included in 'Other'.

** Centrelink began opening from May 1997 but did not completely replace the CES until May 1998.

\footnotetext{
${ }^{5}$ Job seekers include those in employment as well as the unemployed.
} 
Early case $m$ anagem ent ( $V$ ictoria and the Com $m$ onwealth)

Case management for employment services was initiated by the Victorian Labor

Government after research found that many long term unemployed were confused and ignorant about the existence of and their eligibility for Commonwealth labour market programs. This led to the creation in 1987 of a small program, JobLink, which offered outreach services and individualised counselling. Counsellors were also required to directly canvass employers for suitable vacancies. Initially the Government provided all its own employment services, however, late in 1988, grants were given to 10 community organisations for this purpose. Funding was allocated via a grant system and there was no tendering process but an incentive structure existed as grants were only paid according to placement outcomes. The program was renamed Community Business Employment Program in 1992 by the new Victorian Coalition Government.

From 1994, JobLink rules were relaxed to allow the private (commercial) sector to compete for tenders but the uptake was small. While the level of assistance per client varied, the average payment was about $\mathrm{A} \$ 1000$ per placed unemployed jobseeker in 1988-89. This level of payment cannot be directly compared with the current (1998) levels of assistance for, prior to 1997, case managers were able to access Commonwealth wage subsidy, training subsidy or job creations programs which no longer exist. ${ }^{6}$

Several other Australian state governments have copied this general model. NSW uses more community-based providers and focuses on youth and mature workers. Training outcomes were emphasised more than employment outcomes compared with Victoria. South Australia is more targeted towards youth and Western Australia operates a lower level placement service. 
The Commonwealth Government gradually increased its level of job placement and matching services from the late 1980s. Job Clubs were established in 1988 to provide assistance with job search and job application techniques. The (old) Newstart program began in 1989 as a job and training subsidy scheme to assist the long-term unemployed. It included intensive interviews, a doubling of labour market program places and a change in the unemployment benefits incomes test for these people. In July 1991, it was converted into the (new) Newstart scheme that was extended to all unemployed. Activity agreements and case management was introduced. The Skill Share program was established in 1989 to offer counselling, placement services, work experience and short vocational and personal development courses (via the community sector) to the most disadvantaged jobseekers, especially the long term unemployed.

Between 1991-92 and 1992-93, the Government more than doubled the labour market assistance to jobseekers. Under the nomenclature of Working Nation (which ran from May 1994 to March 1996), it re-emphasised intensive counselling services by the establishment of the Employment Services Regulatory Authority (ESRA) and for the first time outsourced some of its case management functions. ESRA was responsible for overseeing and funding private (commercial), community (non-profit) and government providers. However, government provision was always intended to dominate. During 1995-96, the government provider, Employment Assistance Australia, accounted for 77 per cent of referrals. In addition to the establishment of ESRA, Working Nation increased targeting toward the very long-term unemployed and those 'at risk', and guaranteed everyone in this group a job (partly through access to a job creation program). It also

\footnotetext{
${ }^{6}$ These were called JobStart, JobTrain, New Work Opportunities, and JobSkills.
} 
imposed higher penalties upon people who did not participate. Over A $\$ 500 \mathrm{~m}$ of labour market program expenditure was contracted out to program providers in 1993-94.

Private and community providers of case management services began operation in July 1995. There were about 300 providers operating at 550 sites across Australia. Forty per cent were from the private sector, 50 per cent from the community sector and 10 per cent from state, local government and education institutions. Tenderers compete for the right to service an unemployed person on the basis of the quality of services they could offer. The rate of payment from the Government was fixed on the basis of benchmarked costs and ranged from $\mathrm{A} \$ 300$ to $\mathrm{A} \$ 3500$. However, because payments depended partly on outcomes, there was a pecuniary incentive for provider to place as many unemployed jobseekers as they could. A positive outcome was placement for at least 13 weeks in unsubsidised employment, a labour market program, full-time education or a training program.

\section{8 fully contestable placem entand case m anagem entm arket7}

Following a change of government in March 1996, the Labor Government labour market programs were formally abolished and a compete re-organisation of the existing placement and case management services were announced. From 1 May 1998 the CES was abolished, the DSS was re-structured and the majority of placement and case management services was formally tendered. Funding for all employment related services was cut by about half.

The old system whereby the DSS assessed a persons eligibility for unemployment and related benefits and the role of the CES as the first port of call for job or employee

\footnotetext{
${ }^{7}$ Further details can be found on http://jobnetwork.gov.au/
} 
search assistance, was replaced with a one-stop shop called Centrelink. Centrelink now administers both benefit or pension enquiries as well as providing low level placement services. It supplies free job search facilities (computer, telephones), collects and displays job vacancies (a new National Vacancy database has been established), and assesses people's right to further employment assistance including case management. Centrelink also formally administers the mutual obligations of youth and the unemployment benefit recipients, although it has to rely on external providers for some notification. In addition, Centrelink retails customer services originating from the Department of Health and Family Services and the Department of Primary Industry and Energy as well as the abovementioned income transfer and employment services.

Centrelink is, and will always remain a government-operated service. Because it has responsibility for assessing the level of individual and family income support, it must remain under direct government supervision. Many of the officers in Centrelink have previously worked for DSS.

Part of the formal duties of Centrelink staff is to assess people's degree of eligibility for labour market assistance. Using a points based Jobseeker Classification Instrument, staff determine whether or not people qualify for case management, and if so, what level. Following classification, many, but not all, unemployed jobseekers and people seeking an apprenticeship or traineeship are referred by Centrelink staff to a provider (in the Job Network) for government funded services in job matching, job search training and case management.

The Job Network is essentially an expansion of the old ESRA structure. It is a network of over 300 government, private and community providers of placement and 
case management services. The rights to provide services for basic job matching and job search training are awarded on a competitive price basis. ${ }^{8}$ These prices range from under A \$100 to a few hundred dollars per successfully placed client. Successful tenderers for case management however, were selected on the basis of their assessed ability to provide quality services to the unemployed not price in the first tender round. The rate of payment was fixed but dependent upon outcome. In the second tender round the price for intensive assistance was open to tender as well.

Following a review of the old case management system, the definition of outcomes differs from the old ESRA program. Outcomes are defined in terms of sustained employment in an unsubsidised job; labour market programs are excluded. Formally defined labour market programs no longer exist and any wage or training subsidies for the unemployed must be paid out of the performance fee (in the first tender round this ranged from $\mathrm{A} \$ 3000$ to $\mathrm{A} \$ 9200)$. The Government department of employment (DEETYA or DEWRSB) controls the tendering process, monitors the performance of all providers, develops processes for determining provider and jobseeker eligibility, maintains information systems, evaluates and monitors performance, pays provider and handles complaints. The tendering process, the referral process from Centrelink to a Job Network provider, the way in which the Job network processes are all subject to strict guidelines and formal semi-legal procedures and contracts.

All unemployment benefits beneficiaries (and many other categories of DSS clients, people seeking an apprenticeship, traineeship and all youth 15 to 20 years) are eligible for job matching services. Jobseekers are not referred by Centrelink but can initiate contact with up to 6 Job Network providers. A fee is paid if a person is placed in

\footnotetext{
${ }^{8}$ Since its inception, there have been two rounds of tendering. The rules have varied slightly.
} 
an open job offering more than 15 hours per week paid work. Bonus payments are given if the person was previously in long term unemployment.

All unemployment beneficiaries are eligible for job search training but must be referred by Centrelink (who will only refer 94000 people in the initial 19 month contract period). Centrelink will only refer people who are assessed as job ready. Fees are paid for successful placement in open employment.

Case management (or intensive assistance) is restricted to jobseekers who qualify under the points test. These people are either 'at risk' or are long term unemployed. In the first contract period (19 months), an estimated 548000 people will qualify for this assistance. ${ }^{9}$ Fee instalments are paid up-front, when there is a successful interim placement in education or training and if there is a successful final outcome in open employment. Payments are made only if outcomes are sustained for 13 and 26 weeks. The level of payment varies with the assessed disadvantage of the jobseekers and the level of outcome achieved. Because of the up-front fee, it is difficult for job seekers to change their provider if for some reason there is a breakdown in the relationship. In addition, Job Network providers can be paid for assisting jobseekers to establish their own small business, but the business plan must be approved by the department.

Community and private sector organisations compete for the right to become a Job Network provider on the basis of price and quality. Like the old ESRA system, organisations are also screened according to experience, quality of staff, organisational stability and fiscal responsibility. All types of providers, including government agencies,

\footnotetext{
${ }^{9}$ In addition, there is a program (Community Support Program) for people who are not regarded as ready for case management. These include chemically dependent people, those without stable accommodation and people with debilitating personal needs. Provision of services under this program is also contestable and a fixed payment structure exists.
} 
are subject to the exactly the same tendering process. Successful Job Network providers have very broad discretion over how they can spend their up-front and outcome fees. In addition to counselling, money may be spent on wage subsidies, training subsidies or inhouse training programs. Organisations may keep the entire fee as income and they are free to charge both jobseekers and employers fees as well. The later would of course affect their outcomes and subsequently the outcome fee rate.

The department determines which organisations can qualify as a Job Network provider and monitors their success rates. Job Network providers are require to notify Centrelink if there are any breaches of mutual obligation and all unemployed jobseekers are obliged to comply with referrals from Centrelink. Job Network providers cannot reject any referral from Centrelink but jobseekers have a choice of provider if vacancies exist in that organisation. There are time limits for the referral processes.

\section{Reasons forcontracting out}

While the underlying cause of the shift towards outsourcing employment services can be reasonably attributable to changed academic climate, four proximate factors have been cited (formally or informally) as reasons for increasing the separation between the funding and provision of employment services. The first informal reason relates to accidental or unrelated political factors; the second, to the desire by the government to increase the quality of services for the unemployed; the third, to reduce costs and the fourth, to be seen to be adopting a new policy direction from their political predecessors. In no instance was saving money and cutting costs considered explicitly as a motive for contracting out although increasing the quality of a service for the same cost is of course the same as cutting costs. 
While the extension of JobLink to community provision in 1988 was not tendered, and therefore not strictly in accord with a proper contestable model, it is significant because it was the first example of opening the provision of employment services beyond the government sector. It thus should be seen as the first 'toe in the water', the success of which would colour future ventures. Like many innovations, this move arose more by accident than design. At the time, government funding for 8 large community organisations in Victoria was being reduced and they were compensated with JobLink funding as a part-contract part-grant. Extension of the Community Business Employment program to the private sector followed a change of government in 1992. However, few businesses tendered, possibly because they did not have staff who were experienced in dealing with disadvantaged jobseekers.

The inclusion of formal tendering to the community and private sectors by the Commonwealth Government in 1994 was undertaken to maximise the quality and scope of services. Different organisations offered different skills, had experience in dealing with different types of people and had already established niches providing other types of services to the targeted client group. Providers were accordingly encouraged to specialise in providing certain services (placement, case management, apprenticeships etc) or in serving specialised groups (types of disability, youth etc). The decision to tender was made 'in principle' rather than based on a formal assessment but the Commonwealth was also influenced by the successful outcomes under the community provisions of JobLink.

The change in 1998 to large scale outsourcing of placement and case management services appeared to be guided by both the successful review of tendering under Working Nation and also by the need for the new Coalition Commonwealth Government to 
distinguish its employment policies from Labor. By tradition, Coalition parties are more business orientated than Labor and a move in this direction would be regarded as politically strategic. Most of the modifications in the new Job Network-Centrelink arrangement flow directly from a (then) DEETYA review of Working Nation in 1996 and should be regarded as part of the on-going bureaucratic process to improve the efficiency of government programs in general (DEETYA 1996).

In principle, the (then) DEETYA supports some tendering in its labour market programs because they believe that it provides quality, cost effectiveness in a flexible and responsive manner (CES Advisory Committee 1992).

\section{M echanism s used to support contestability}

The tendering out of placement and case management services prior to May 1998 is controlled by an extensive set of rules, processes and incentives to maximise the jobmatching rate of clients and to minimise the extent of creaming.

1. The tender process. Tenderers are assessed on their probable ability to achieve a successful placement rate for their designated client group and in the case of job matching and job search training, on price as well. Experience, the qualifications and experience of staff and the probity of the organisation are relevant. Competition for case management is based partly on quality, so smaller organisations are viable and can contribute toward a wide consumer choice set. The initial tender period was 19 months. This was thought to be short enough to permit fine tuning and respond to different market needs but long enough to give contractors the incentive to invest in physical capital, staff training and goodwill. 
2. Manuals. Most Commonwealth Government departments, most state governments and one local government association provide detailed manuals/guidelines for general contractors. The tender process for employment services has a strict protocol.

3. The payment structure. Providers are paid according to the level of disadvantage of the person. Jobseekers are classified according to a strict formula (using the Jobseeker Classification Instrument) into five categories ${ }^{10}$. Normal, 'job ready', or disadvantaged. Creaming may still occur within and between categories. This will occur if the Jobseeker Classification Instrument and the payment structure do not reflect the difficulty of obtaining open employment for each group. However, creaming should be limited by the provision that a provider must accept all jobseeker referrals from Centrelink and by the performance monitoring process. In the latter, the department monitors providers records of the percentage of jobseekers they place in a job and who remain in that job for 13 and 26 weeks; the average quarterly reduction in allowances paid and the average time taken from referral to placement. If the department finds that placement rates are systematically low or high for different types of jobseeker, then they should alter the Jobseeker Classification Instrument and the relative payment schedule accordingly.

4. Monitoring process. The department will monitor each provider according to the percentage of jobseekers achieving positive outcomes, the average quarterly reduction in income support and the average length of time taken for each referral to achieve an outcome.

\footnotetext{
${ }^{10}$ Limited discretion is given to award points to people who have non-measurable labour market difficulties related to motivation etc.
} 
5. Information technology. A computerised and on-line information, monitoring and payment system has been established to reduce costs associated with the use of an intermediary.

6. Complaints and appeal services. A free formal complaint service run by DEETYA exists for both jobseekers and providers. Complaints may also be addressed to the Commonwealth ombudsperson. Participants also have access the to Social Security Appeals Tribunal and the Administrative Appeal Tribunal.

7. Legal requirements. Providers are subject to several laws which aim to ensure a fair service is given including the Freedom of Information Act 1982, the Crimes Act 1914 and the Privacy Act 1988. Successful tenderers must agree to a formal Code of Conduct. To ensure compliance by referred jobseekers, they are required to sign an Activity Agreement, which details a timetable for labour market rehabilitation. This constrains both the provider and the jobseeker.

8. Jobseeker and employer choice. Insofar as is possible, jobseekers can nominate the provider to be referred to. Unless capacity is full across providers, this creates an additional level of competition. However, once a job seeker has started intensive assistance with a provider it is difficult to change. Employers have a greater choice over which provider(s), if any, they will lodge a vacancy with. This vacancy may be common knowledge to the whole industry or confidential to one or more provider(s). Again, this creates competition between providers to better match both ends of the labour market.

9. Jobseeker satisfaction surveys. The department surveys clients of providers to record their satisfaction levels. 
10. Benchmarking. The department may in the future undertake a benchmarking study to further raise the level of competition. Since 1996, D(E)ETYA has also been running a longitudinal survey of clients.

\section{E ffects of contracting em ploym ent services (A ustralia)}

Evaluations of Australian placement and case management services are relatively limited and studies on the effect of the transformation to a contestable market do not exist.

Nevertheless, the findings from related reports should be of interest insofar as they throw light on the need for and conceivable effects of outsourcing. Several formal and informal studies exist on the effectiveness of basic placement services (Wooden and Harding, 1998), job search assistance programs (DEET, 1994, DEETYA, 1997, Stromback, Dockery \& Ying 1998, 1999) and case management programs (DEETYA, 1996). Evaluations of programs with combined job search, training, case management and employment components are not reported due to the difficulty of separating the effects.

The survey of CES employer clients by Wooden and Harding (1998) found that the majority of employers did not have high expectations of either the CES or recruits attracted by them. Many believed that the CES was mainly interested in shifting people off their books and that the staff did not have the skills to appropriately match people with the sort of jobs on offer. Further, employers thought CES staff displayed poor service delivery skills and had little interest in developing on-going relationships with firms. However, the authors also believed that some of the dissatisfaction with the CES existed because their services were free. Expectations of free government services often know no limits. Nevertheless, the report recommended a cultural shift in the CES and a reorientation toward employers needs. 
As part of their regular evaluations of labour market programs, DEETYA (1997) (and the former DEET) estimated that job search assistance programs increased the employment rate of participants (at 3 months post-program) by 10 percentage points. However, Stromback, Dockery \& Ying (1999) who only found a 2 percentage point increment. The Stromback et al results are also consistent with evaluations from the UK, USA, Canada, Sweden and NZ which found that the effect of intensive placement services are, at best, only marginally positive (see Fay 1996, Webster 1998).

The Stromback et al papers also found that the two longer employment programs (wage subsidy and job creation with some training) had the largest positive effect on an individual's outcome. Both these programs were about 26 weeks in length. If the success of these programs is attributable to their length, then the new system of case management is less likely to be as successful as the Working Nation programs because the compensations levels under the Job Network preclude job creation programs of this length and make wage subsidy programs difficult to finance. The new Job Network system is based upon about half the funding provided for Working Nation.

An unpublished evaluation of JobLink in 1990 found that government providers had a higher employment placement rate (45 per cent) than the community sector providers ( 39 per cent), however the authors suggested that this difference may be attributable to local differences and the background characteristic of clients. Creaming was found to have occurred. ${ }^{11}$ In the 14 months to September 1989, disabled clients and clients with lower educational attainment and longer unemployment durations had lower placement rates. A jobseeker unemployed for less than 12 months, for example, was nearly twice as likely to be placed as some-one unemployed over 5 years. 
The evaluation of case management under Working Nation did not indicate the marginal effect of case management on participants outcomes or the effect of introducing outsourcing under ESRA (DEETYA, 1996). However, it found that the placement rate of community and private sector providers equalled the government provider rate after controlling for jobseeker category, job seeker characteristics and the length of time the provider had been providing this sort of service. Given that government providers had a caseload which was at least 30 per cent higher than non-government providers, labour productivity must have been higher in the non-contestable government sector. ${ }^{12}$ The government provider was the provider of the last resort, was not paid on the basis of outcomes and thus was not facing market incentives. Accordingly, these results run contrary to the theory of contestability: the competitive (private and community) sectors had a lower not higher labour productivity. This result may have occurred because according to the Industries commission (IC, 1996), the main source of efficiency gain from contracting out arises from improvement and reform to management and work practices and given that both government and non-government providers were new to the market, this was not relevant. ${ }^{13}$ However, it does suggest caution when projecting hypothetical benefits from contracting out.

Data from the Job Network is still not open to public scrutiny. There has been a release of summary data but given the number of departmental adjustments to the data and lack of third party ability to scrutinise the data, its value is much diminished.

\footnotetext{
${ }^{11}$ Data on placement rate by jobseeker characteristic was only available for the government providers.

${ }^{12}$ However without further information on relative wage rate and differences in local labour markets, we cannot say from this that efficiency has been better or worse or costs higher or lower.

${ }^{13}$ Government case managers may have been more efficient because of their greater knowledge of labour market programs. However, one would have expected that this gap would have been closed in the first 10 months of operation. Furthermore, non-government case managers have more professional training and experience in counselling per se than government workers.
} 


\section{CON CLUSION S}

Given the small role which either the government and private job placement services have had in finding jobs for the unemployed (Table 2) and the limited effects job search training has in improving jobseekers chance of finding work (Stromback, Dockery and Ying 1999, 1998), the greatest potential source of efficiency gain from tendering out job matching and job search training is a reduction in costs. Even if the new arrangement doubled the effect of job search training, its marginal contribution, assuming the Stromback et al estimates are valid, would increase from a very small 2 percentage points to a small 4 percentage points. ${ }^{14}$ Nevertheless, this does not excuse poor work and management practices within the government funded placement sector. Tendering out may be a reasonable strategy if, as is claimed by the Industries Commission, it is a quick and effective way to change entrenched, archaic and deficient management and work practices and to allow staff to specialise in clients' needs. Contracting out can often enhance client focus. Alternatively, internal reforms through the provision of new monitoring systems and a more directed incentive structure may result in better service within a government agency without the costs associated with tendering, contracting and arms-length control.

Results from the reviews of outsourcing case management under ESRA and JobLink, suggest that non-government provision of services will necessarily be superior. Even if introducing contestability into this market does make it more efficient, other things equal; other things are rarely equal. There are often large once off-costs such as redundancy and once off and continuous learning costs. There are costs to the community

\footnotetext{
${ }^{14}$ That is, the employment rate of former jobseekers would be 4 percentage point higher at between zero and 12 months after the program had ended.
} 
when competition precludes co-operation and costs to the government through a loss of skills and knowledge. If there are grounds for believing that the existing system is working well and no evidence of poor client service, then the case for contracting out is small. The Industries Commission recommended that contracting out should be assessed on a case-by-case basis. Productivity gains were most likely to come from a reform of management and work practices and specialisation and tendering out was not the only way to achieve this.

Until researchers have access to government data on the employment services, independent evaluations of the performance of the Job Network be difficult.

\section{REFEREN CES}

Baumol, W. (1982) 'Contestable markets: An uprising in the theory of industry structure', American Economic Review, 72(3), 1-15.

Bishop, M., Kay, J., \& Mayer, C., (Eds) (1994), Privatization and Economic

Performance, Oxford University Press.

Boreham P, Roan A \& Whitehouse G (1994) 'The regulation of Employment services;

Private Employment Agencies and Labour market policy', Australian Journal of Political Science, 29, 541-555.

CES Advisory Committee (1992) Review of Tendering for labour market programs,

Canberra: Australian Government Publishing Service.

Cubbin, J., Domberger, S., \& Meadowcroft, S., (1987), 'Competitive tendering and refuse collection: identifying the sources of efficiency gains', Fiscal Studies, 8(3), pp. 4858. 
DEET, (1994), Net Impact Study of Job Clubs, Evaluation and Monitoring Branch, EMB Report 5/94, Canberra.

DEETYA (1996) Working Nation: Evaluation of the employment, educational training elements. Evaluation and Monitoring Branch. EMB Report 2/96.

DEETYA (1997) The net impact of labour market programs, Evaluation and Monitoring Branch, EMB Report 2/97.

Domberger, S., and Li, E.A.L., (1995), 'An ordered-probit analysis of price and performance in competitively tendered contracts', Australian Economic Review, 2’95, pp. 14-22.

Domberger, S., and Piggott, J., (1994), 'Privatization policies and public enterprise: A survey', in Bishop, M., Kay, J., \& Mayer, C., (eds), Privatization and Economic Performance, Oxford University Press, pp. 32-61.

Domberger, S., and Rimmer, S., (1994), 'Competitive tendering and contracting in the public sector: A survey', International Journal of the Economics of Business, 1(3), pp. 439-53.

Domberger, S., (1994), 'Public sector contracting: does it work? Australian Economic Review, 3'94, pp. 91-6.

Domberger, S., Hall, C., \& Jefferies, M., (1995), Competitive tendering and contracting in Commonwealth Government Agencies: The 1995 survey findings, Graduate School of Business, University of Sydney.

Domberger, S., Hall, C., \& Li, E.A.L., (1995), 'The determinants of price and quality in competitively tendered contracts', The Economic Journal, 105, pp. 1454-70.

Domberger, S., Meadowcroft, S., \& Thompson, DJ, (1994), 'Competitive tendering and efficiency: The case of refuse collection', in Bishop, M., Kay, J., \& Mayer, C., 
(eds), Privatization and Economic Performance, Oxford University Press, pp. 188207.

Fay, R. (1996) 'Enhancing the effectiveness of active labour market policies: Evidence from program evaluations in OECD countries', mimeo, OECD.

Wooden, M. and Harding, D. (1998) 'Recruitment practices in the private sector: Results from a national survey of employers', Asia Pacific Journal of Human Resources, 36.

Hodge, G., (1996), Contracting out Government Services: A Review of International Evidence, Graduate School, of Government, Monash University.

IC (1996), Competitive Tendering and Contracting by Public Sector Agencies, Industry Commission, Report no 48, AGPS, Melbourne.

Stromback, T., Dockery, M. \& Ying, W. (1998) 'Transitions in the labour market: Evidence from the survey of employment and unemployment patterns', Melbourne Institute Working Paper Series, 1/98.

Stromback, T., Dockery, M. \& Ying, W. (1999) 'Labour market programs and labour force status', Australian Bulletin of Labour, June, pp 159-178.

Webster E. (1998) 'Microeconomic evaluations of Australian labour market programs', Australian Economic Review. 